\title{
Sovereign Claims and Possessions - The Beginnings of the Territorial State
}

\author{
Douglas Howland ${ }^{1}$ \\ ${ }^{1}$ David D. Buck Professor of Chinese History, Department of History, University of Wisconsin-Milwaukee, P.O. Box 413, \\ Milwaukee, WI 53201, USA \\ Correspondence: Douglas Howland, David D. Buck Professor of Chinese History, Department of History, University of \\ Wisconsin-Milwaukee, P.O. Box 413, Milwaukee, WI 53201, USA.
}

Received: September 4, 2019

Accepted: September 29, $2019 \quad$ Available online: October 17, 2019

doi:10.11114/ijsss.v7i6.4566

URL: https://doi.org/10.11114/ijsss.v7i6.4566

\begin{abstract}
Royal claims from the age of exploration persisted into the $19^{\text {th }}$ century, when they began to be replaced by claims to territory on the part of States. Sovereignty over territory was increasingly phrased in terms of "jurisdiction" and, as the State became a territorial entity, an equivalence was posed between "territorial sovereignty" and "territorial jurisdiction." Boundary disputes in the $19^{\text {th }}$ century provide evidence for the transition, and these were invited largely by conflicts over commercial prerogatives in one or another place. Three territorial practices in the $19^{\text {th }}$ century identify the beginnings of the territorial orientation of the State: effective occupation, boundary differentiation, and administrative jurisdiction.
\end{abstract}

Keywords: administrative state, boundary disputes, state jurisdiction, territorial sovereignty, territorial state, territoriality

\section{Introduction}

The business of occupying and possessing territory remains a feature of our world today. As this essay demonstrates, royal claims from the age of exploration persisted into the $19^{\text {th }}$ century, when they began to be replaced by claims to territory on the part of States. Boundary disputes around the globe provide evidence for the transition, and these were invited largely by conflicts over commercial prerogatives in one or another place. When subjects or citizens of rival governments fought over their putative rights to trade or fish or log or mine in a place such as northeastern North America or the West African coast, State representatives intervened in order to clarify rights of possession, property, and jurisdiction.

For territory in the $19^{\text {th }}$ century became closely tied to the administrative State, its sovereignty, and its law. Differing from a sovereign's claim to land and royal subjects who were bound to that monarch by allegiance, the sovereign State had a territorial basis and its citizens were bound by a constitution that asserted their legal rights and duties in that territory. A key mark of that transition was the equivalence posed between "territorial jurisdiction" and "territorial sovereignty." State sovereignty came to mean, above all, State jurisdiction, and it was grounded in territorial possession. The State came to have a territorial basis.

To that end, this essay contributes to the historicization of the European or "international" State system that began with geographer Jean Gottmann in his seminal work, The Significance of Territory, which sought to understand "the spatialization of State sovereignty" by accounting for the variety of State interests in territory (1973, p. 4). More centrally within geopolitics and international relations scholarship, F. Kratochwil (1986) examined processes by which boundary differentiation began to define State sovereignty and territory, and J.R. Ruggie (1993) investigated the historical transformations that constituted the "emergence of modern territoriality" and its attendant single viewpoint for sovereignty. (See also Sahlins (1989) and Collins (1989).) Both of these writers, however, gloss over the $19^{\text {th }}$ century and its significant contributions. The more recent work of historians of international law, such as Martti Koskenniemi (2001) and others (Anghie, 2004; van der Linden, 2014), demonstrates that the territorial State is a $19^{\text {th }}$-century creation. This essay specifically examines territorial practices in the $19^{\text {th }}$ century.

The work of Kratochwil and Ruggie coincided with John Angew's (1994) accusation that IR had fallen into a "territorial trap." Agnew charged that IR scholarship generally lacked historical consciousness and left unexamined its widespread assumptions regarding "the State's essential territoriality." In response, constructivists including Alexander Murphy 
(1996) sought to historicize the international State system as a group of territorial States, including the ocean environment of this evolving State system (Steinberg, 2001). A corollary body of work, inspired by Foucault's analysis of discursive practices, has examined the construction of spatiality in order to investigate how State administration organizes space into State territory (Crampton and Elden, 2006; Delaney, 2005; Hannah, 2000). Within the field of law, Paul Alliès (1980) also provided a powerful analysis of the administrative construction of territory. Other scholars, however, have criticized constructivism for its unwillingness to acknowledge the reality of space, and have enlisted the history of cartography in early-modern Europe. Jordon Branch (2011) and Jeppe Strandsbjerg (2010) agree that territory is constructed, but insist that a developing consciousness of space and territory mapped conceptions of the State as it took form in the modern period.

This essay responds in part to a question raised by Strandsbjerg: "how was it possible to relocate sovereignty from the ruler of a State to a fixed notion of the territory?" Like him and Branch, I argue that cartography helps to explain this question. And like many constructivists, I share an interest in analyzing discourse in order to demonstrate a shift of constructed realities. But I do not agree that to identify metaphorical language is to explain these constructions. Tuomas Forsberg (2003, pp. 8-10), for example, faults constructivism for making "no meaningful distinction between material boundaries and symbolic ones, between real and virtual space." In order to emphasize the "consequences of conceptualization" in the culturally meaningful construction of phenomena, he turns to linguistic metaphors - territory as the body of the State or territory as private property - and how they might influence territorial practices in world politics. Even if a "private law analogy" was once "projected onto territorial issues," I do not believe that identifying with one's State in the same way that one might identify with one's private property helps to better explain territorial disputes (pp. 16, 20). The issue is not metaphorical. Yes, "property" constitutes a new characteristic of territory; as Kratochwil pointed out (1986, p. 36), "Boundaries-i.e., legally relevant distinctions-existed only in private legal relations, where they governed property rights." Property and territory were mapped onto each other at the outset of the modern State.

Based on cases from the archives - largely those of the UK-I argue in this essay that personal royal possessions became State territorial possessions. In the transition from monarch to State, royal possessions were renamed State territory. Moreover, the institution of State territory was informed by private property. As we see in the case of the northeastern boundary dispute between His British Majesty and the USA, personal deeds to property, duly surveyed and publicly recorded, provided a template for the State's territory, properly surveyed and publicly acknowledged. Personal property practices were integrated into the State's territorial practices. This shift from personal to public offers a partial answer to Strandsbjerg's question as to how sovereignty passed from the ruler of a State to a fixed notion of the territory.

This is not to declare that territory as possession was considered to be State property in the $19^{\text {th }}$ century. The Treaty of Versailles (signed in 1919), after all, differentiated between German possessions and German property in assigning those to victorious States. In the International Court of Arbitration and its successor, the International Court of Justice, the operative word has been "title" (rather than deed), as one or another State sues to assert title to an island or strip of land. The focus on "title" has given rise to a set of new legal concepts that concretize property - such as original title, historic title, and aboriginal title - and these have arisen out of territorial disputes over lands once colonized by Europeans (see Fry and Loja, 2014; Gioia, [2013]; Mostart, [2013]). ${ }^{1} \quad$ Today, nearly 200 years after the earliest of the cases in this essay, international lawyers comfortably write of State territory as State property-a ground on which Marxist analysis coheres with that of the status quo. Where China Miéville (2006) critiques the international system as a collection of individual property owners writ large - and his argument is based on the capacity of the early modern State to defend its subjects' contracts and claims to property, and in turn its own-Michael Strauss (2015) recounts the apotheosis of the analogy between private property and State territory, which has been secured through the figure of title to land.

In spite of strong objections like that of dissenting Judge Mahomed Ali Currim Chagla, who insisted (in his 1960 decision in Rite of Passage over Indian Territory, cited in Strauss, 2015, p. 41) that a citizen lacks key powers of the State - such as eminent domain or other legislation concerning property - territory as "State property" is conceptually no longer an analogy. Where it provided a model in the $19^{\text {th }}$ century, Norman Hill $(1945$, p. 5) asserted as early as 1945 that state territory was being treated as property. It has now become the legal idiom, so that today, State territory is property. Legal concepts have the capacity to restructure reality. One phenomenon examined below (see section 3) is the concept of terra nullius or "vacant land," which, in the $19^{\text {th }}$ century, was linked to "effective occupation." In the postwar

\footnotetext{
${ }^{1}$ Some scholars of international law now reify the postwar assemblage of ICJ cases as a "law of territory"- as though there exists a coherent and codified body of law akin to, say, the UN Charter, or the 1969 Vienna Convention on the Law of Treaties, or UNCLOS. See, for example, Huh (2015).
} 
case history, terra nullius has become a formal legal concept, but this was not possible in the $19^{\text {th }}$ century.

The purpose of this essay is to supplement the work of geopolitical and international relations scholars with historical cases from the archives, in order to shed light on the practices that define the territorialization of the State. This essay represents a discursive analytical intervention into historical chronology. That is, it traces an interplay between conceptual changes and the development of territorial practices. Section 2 below critiques royal claims during the "age of exploration," which were based on discovery and rituals of possession that proved inadequate. Sections 3 , 4, and 5 examine respectively effective occupation, boundary differentiation, and administrative jurisdiction as the key State practices that underlay the territorial State as it was constructed in the $19^{\text {th }}$ century. Effective occupation called for administration of a claim, in order to reconstruct it as State territory. Boundary differentiation, at the same time, employed treaty-making and surveying techniques in order to enhance territorial administration and to define the administrative jurisdiction of place that has come to be called the territorial sovereignty of the State.

\section{Royal Claims to Territory Based on Discovery and Rituals of Possession}

The long history of European exploration and territorial acquisitions from the 1400s through the 1800s reveals a common set of principles in the claims that were made to non-European lands. It is clear that "discovery" per se was never a valid basis for a claim. Instead, some symbolic "act of possession" was required to substantiate a claim. Where the Portuguese and French conducted a rather simple ceremony in asserting sovereignty - a public proclamation of the dominion or lordship of the crown over the land and the erection of a cross or column or pillar in stone or wood - the Spanish and English enacted formal rituals of possession, which might include not only the public proclamation of royal possession but also markers bearing royal arms, signs to mark territory as a possession, crosses, the clearing of trees as a sign of occupation, and sometimes the marking of drinking water (KLM, 1938, pp. 31f, 34, 39, 74, 98f, 105-108). English explorers often practiced a "turf and twig" ceremony that mimicked the "common-law procedure of enfeoffment," in which "the foeffor made a delivery of real property to the foeffee by handing the latter a clod of earth and a twig from the land in token of the latter's seisin" (KLM, 1938, pp. 57f, 63f). When Hernan Cortes took possession of "Mexico" for the King of Spain, "he drew his sword, and ... made three cuts in a large silk-cotton tree... and cried that if any person should raise an objection he would defend the King's right with his sword and his shield, which he held in his other hand"- -whereupon the soldiers in Cortes" company "cried that he did right to take possession of this land in His Majesty's name" (Diaz, 1963, p. 71).

Such claims were problematic, however, because unless a territory were visited regularly, rotted wood and fallen stones might obscure the claim. Moreover, ship captains did not always keep reliable accounts of their voyages and landings, preventing a successor from precisely locating a claim. This uncertainty accounts for the increased reliance on maps and advances in European cartography in the $16^{\text {th }}$ century; new maps were immediately useful as both tools for exploration and representations of territorial claims. It was important to know who claimed what (Turnbull, 1993, pp. 25, 42, 44; Thrower, 1996, 63f, 116f). The Portuguese had "discovered" the Molucca (Maluku) Islands in 1511 but did not claim them; in 1521, the Spanish visited the Moluccas and later claimed them - giving rise to a dispute that first invoked the Pope's purported division of the world in the 1494 Treaty of Tordesillas but then required a new treaty for clarification in 1526 (see Steinberg, 2001, pp. 75-86). The latter Treaty of Saragossa (Zaragoza) declared that the meridian $17^{\circ}$ east of the Moluccas determined Portuguese territory; so the Moluccas were "owned" by Portugal and everything to the west-most of the Pacific Ocean - could become the property of Spain (KLM, 1938, pp. 7-10, 28, 36f). Norman Thrower has noted that one result of the circumnavigation of the globe by Ferdinand Magellan and Juan Sebastián de Elcano between 1519 and 1521 was to encourage the production of a new map in 1524 by Juan Vespucci-a double-hemispheric projection — which helped to settle the dispute over the Moluccas (Thrower, 1996, pp. 69f, 75; also see Strandsbjerg, 2010, pp. 89-119).

Hence, "discovery" alone was not accepted as the basis of a claim. Instead, "possession" in some form stronger than a symbolic act was necessary, and the surest sign of possession was occupation (Fitzmaurice, 2012; Simsarian, 1938). ${ }^{2}$ When the King of Portugal, for example, complained to England in 1561 that English subjects were trespassing into Guinea and other establishments of the Portuguese Crown in Africa, the English Crown retorted that "only places where the Portuguese had fortresses or were paid tribute were under Portuguese sovereignty" (KLM, 1938, p. 28f). The authority of the Pope had no bearing upon the English in this dispute - nor upon the French or the Dutch in any other. Yet decades thereafter, the Portuguese, settled in Brazil and sufficiently armed, successfully compelled an outpost of

\footnotetext{
2 John Locke, whose theory of "First Taking" or "First Occupancy" was based on the idea that a man's application of labor to what he finds in nature makes it his property, emphasized that occupation required both working the land through one's labor and marking it as one's own through some enclosure that restricts others' access. See Locke (1988, pp. 289-91 - i.e., II, II 30-32); and Waldron (1988, p. 173f).
} 
French colonists in the 1610s to leave a coastal area located ambiguously between Brazil and Peru; Portugal claimed the area and could forcefully defend its claim (KLM, 1938, pp. 30f, 68-78; Simsarian, 1938).

Disputes over claims could reignite after quiet centuries. Consider the 1860s dispute between Portugal and Britain over the island of "Bulama" (Bolama), over which Portugal claimed a "right to sovereignty" and which thus constituted a part of their colony of Portuguese Guinea. Portuguese sovereignty was based on Portuguese traders harvesting timber from the island beginning in the late 1500s. The local Bissago people subsequently began to claim the island in the early 1600s, with no consequence to Portugal, but the arrival of British settlers and the British Navy in 1792 forced the question. British representatives first argued that Portugal had not proclaimed its right to sovereignty over Bulama to other nations properly, as international legal authorities recommended, and that the formal Portuguese claim of April 1753 was an "empty ceremony" without actual settlement or cultivation of the soil. (Portugal had asserted a claim in 1753 in order to fend off French interest in the island.) The British next enlisted the aid of the "King of Bissagoes" who professed ignorance of Portuguese actions and reasserted his claim to the island, which encouraged Britain to argue that Portugal had obtained not a right to territorial sovereignty but only a right of usufruct to cut timber, and to conclude that Portugal could not prove that the Bissagos had abandoned the island in the $18^{\text {th }}$ century. Eventually, in 1827 , Britain contracted with the "King of Biafares" to lease the island, which Portugal loudly denounced. As with other disputes in West Africa, the British claimed to be motivated by a desire to stop the Portuguese slave trade. The stalemate continued for three decades, and the British effort to assert their claim by force of arms in the 1860s was ineffective, so the dispute was submitted to arbitration by the USA, whose President Grant in 1870 ruled in favor of Portugal (CO file 879/2; see also "Arbitral Award... 1870").

As we see repeatedly in the $19^{\text {th }}$ century, the passage of time works to recast territorial claims in new modes. The simple announcement of a claim must be enforced with settlers and fortifications and girded with treaties. The Bulama case is exceptional in my reading in that British officials, in order to fortify their territorial claims, invoked "authorities" among international legal scholars. They cited Vattel, Martens, and Woolsey on the need to settle, cultivate, and otherwise properly occupy a territorial claim. Such references to legal authorities would increase after the "scramble for Africa" in the 1880s; at the same time, the legal procedure of arbitration became a significant alternative to violence in the $19^{\text {th }}$ century (see Harris, 2015).

During the "age of exploration," then as now, claims to territory were motivated by competition for profit and property - and, increasingly, geopolitical strategy. The Portuguese, Spanish, and Dutch were keen to garner exclusive trading rights with the peoples whom they encountered in the "East Indies" and fashioned agreements with local leaders or "kings" to that effect. These agreements might be understood as signs of submission to European monarchs (or a republican government in the case of the Dutch East India Company, or a corporation in the case of the British East India Company), or the payment of tribute as a sign of submission (quite like the relation of the Joseon King in Korea to the Qing Emperor in China), or signs of protection from rival European traders in exchange for exclusive trading rights. Such agreements were frequently challenged by newcomers to an area and invited disputes that, if not promptly settled, produced enduring hostility. The Dutch and Spanish, for example, fought with each other in Mindanao, Borneo, and the Sulu archipelago from the 1650s to the 1750s. As they made and broke alliances with local sultans and chieftains, local conflicts became entangled with Dutch and Spanish claims to trading rights and protectorates. Keller, Lissitzyn, and Mann argue that the Dutch, although initially reluctant to claim territory but committed to safeguarding their primary interest in trade, found it necessary to assert claims to land in the East Indies in the face of Spanish and English competition (KLM, 1938, pp. 19-22, 140f).

\section{Effective Occupation of Terra Nullius}

The $19^{\text {th }}$ century, then, witnessed the appearance of new practices of legal argument in claims to territory. Legal scholars and advisors revisited "occupation" and redefined "effective occupation" as actual settlement or the establishment of government administration. The Act produced by the Congress of Berlin in 1885, for example, described effective occupation as "the establishment of authority ... sufficient to respect existing rights, and as the case may be, freedom of trade and of transit..." 3 ("General Act ... 1885", Art. 35) Other authorities at the time interpreted effective occupation as governmental control "sufficient to provide security to life and property" (Hill, 1945, pp. 146-48).

The uncertainty with discovery or occupation of new territory had always to do with the doctrine of "vacant country" or "unoccupied territory": in the $19^{\text {th }}$ century, this was formalized as territorium nullius and eventually, terra nullius (Fitzmaurice 2007; Fitzmaurice, 2012). The doctrine was something of a misnomer, for most cases were not a matter of

\footnotetext{
${ }^{3}$ A great deal of interpretive debate ensued as to the meaning of le cas échéant, officially translated as "as the case may be" but equally rendered "if need be." The debate left open the question: Was freedom of trade and transit a condition of effectivity or not?
} 
actually "unoccupied" or "vacant" land but the perception of a low level of organization or civilization among the inhabitants. In the "age of exploration," a local leader not deemed sufficiently sovereign could be induced to offer evidence of submission and obedience to the European king, which might be taken for "effective control" by the sovereign European claimant (KLM, 1938, p. 10). This was typically Spanish or Portuguese practice, as we saw with Bulama. By comparison, the French and English made formal treaties or agreements with native peoples in South Asia and North America - for peace, military alliance, trade, or purchase of land - as did the Dutch in the East Indies. Although some explorers were instructed to claim any lands "not previously possessed by any Christian prince," the rulers of some lands in India, the Middle East and North Africa, as well as China and Japan, were considered to possess a sovereign status of equivalent rank (KLM, 1938, pp. 10,13). In the early modern period, the Ottoman sultan was treated as a sovereign equivalent to the king of France (Kuntz, 2015). Likewise, the Chinese emperor and Japanese shogun were sovereigns in their respective lands, and no European explorer ever attempted to claim their territories as "vacant country." Negotiations and treaties were required - especially because, in the persisting context of natural law, both China and Japan continued to have a sovereign status and were capable of acting as sovereign peers of their European rivals (Howland, 2016, pp. 8-11, 27-29, 67f).

In 1886 - prompted by the ambiguities of the General Act of Berlin, 1885-international lawyer Ferdinand de Martitz proposed to redefine terra nullius as "land not under any sovereignty" (Martitz, 1887; see also Fitzmaurice, 2007, pp.10-13). In discussions with the Institut de Droit International, Martitz sought to specify that territory, whether inhabited or not, was available for occupation if it were not under the sovereignty of any member of the civilized family of nations. Although this was a proposal tailored to Bismark's plans for German colonization in Africa, the majority of his fellow members of the IDI found Martitz's proposal groundless and uncomfortably reminiscent of the age of exploration and its valorization of the rights of Christian princes to conquer non-Christians. Because the Berlin Act maintained that "effective occupation" required only that the occupier notify the other powers and establish an authority in the occupied territory or protectorate, the Institut heeded the criticism of Martitz's rival, Éduard Engelhardt, who faulted the Berlin Act and its signatories for their lack of clarity, and proposed that effective occupation be understood to include the various measures also specified by the other articles of the Act: that slavery in occupied territory be abolished; that freedom of religion in occupied territory be maintained; that the rights of the indigenous people be respected; that freedom of trade and transit throughout occupied territory be maintained; and so on (Engelhardt, 1886). In 1889 the IDI's Resolution on Occupied Territory reproduced the majority of Engelhardt's recommendations ("Quatrième commission...," 1888; Resolutions, 1916, pp. 86-88).

Nonetheless, the ambiguities generated by the Berlin Act produced unanticipated problems, for example, in the vast area of the Congo. Arguably based on the precedent of the USA's recognition of the International African Association (IAA) as a legitimate government and sovereign State, French authorities in the French Congo began granting monopolistic concessions to private individuals and corporations in 1898. British traders complained to their Foreign Office that this surely violated the "spirit of the law" enacted in Berlin, which promoted free access to all areas for commerce. Of immediate concern was the creation of "garde-routes" which effectively directed trade through the French Congo, for they were the best-maintained roads. They also effectively controlled British and Dutch traders in that, should those traders be found along those roads, they were reportedly arrested and expelled. The British insisted that this constituted an illegal closure of roads to commerce (FO file 403/328). In the same way that the British Crown had absorbed the East India Company in India, so the Belgian Crown absorbed the IAA and France gradually ceased its practices in the French Congo. General agreement coalesced to prohibit a private individual or corporation from holding sovereignty over its own State-with the curious exception of James Brooke as the "White Rajah" in Sarawak, an anomaly that endured from 1842 to 1946 (see Lowe, 1987, p. 143f; van der Linden, pp. 130-32, 181-201, 203-206).

Martitz certainly represented the age in restricting territorial occupations to the family of "civilized" nations. The 1890s and 1900s witnessed an increasing use of international treaties to transfer titles to land-as acts of international law-and this practice proved as controversial as claims to terra nullius within positivist international law as it developed its doctrine of "civilized society." Because treaties were said to express the sovereign wills of civilized rulers, if a local chieftain were qualified to sign a treaty —or at best, scratch his " $\mathrm{X}$ " on the appropriate line - he must be sovereign and able to transfer African lands to a European power. However, if the local chieftain were not civilized and hence not properly sovereign, the treaty was not a legitimate document and the European power could not rightfully occupy African lands ceded by an illegitimate treaty. As a more acceptable alternative, the European power might negotiate a treaty of "protection" with a local authority in order to acquire the use of territory. Nonetheless, legal authorities raised identical questions about the legitimacy of treaties between China or Japan and the European powers-William Edward Hall, for example, asserted that neither China nor Japan was "civilized" and judged all European treaties with those States to be illegitimate (Howland, 2016, pp. 14-18, 60). Most statesmen deliberately ignored this technical contradiction, for colonial control of African lands and the stability of extraterritorial 
arrangements in China, Japan, and the Middle East depended upon European acknowledgment of the legitimacy of their treaties (Anghie, 2004, pp. 92-96; Koskenniemi, 2001, pp. 138-42; van der Linden, 2014, pp. 76-68, 109-117, 232).

Consider two examples of "vacant land" that lingered into the $20^{\text {th }}$ century. The first demonstrates specifically how Martitz's argument misinformed these controversies. Already in the 1870s, Japan had begun to apply European international law to its relations with China and Korea; after 1909, as colonial master of Korea, Japan maneuvered in effect a "land grab" on behalf of Japan's Korean Protectorate. Japanese legal scholar Shinoda Jisaku, who served in the Japanese administration of Korea, oversaw the maneuver. As Nianshen Song recounts, Shinoda argued that the Kando area north of the Tumen River was effectively terra nullius insofar as it had never clearly been under the sovereignty of either Qing China or Joseon Korea. Shinoda's argument pointed to erroneous maps drawn in the 1710s, which incorporated the fact that Koreans had deliberately misinformed Qing officials about the Qing-Joseon border, but which nonetheless became official Chinese representations of the border region. (The maps were subsequently copied by French scholars and thus became international references.) Two centuries later, when imperial Japan was interested in expanding and solidifying its position against Russia, as well as developing a "Northeast Asian transportation corridor" through the region, newly corrected maps and Martitz's legal proposal to define terra nullius as "land without sovereignty" provided a dubious demonstration that the Kando area belonged to Korea-and hence to Japan. Because Japanese-occupied Korea served as a buffer to Russia, Britain and the other powers were content to let Japan have its way (Song, 2017).

Second is the case of the Spitsbergen archipelago in the Barents Sea between Greenland and Russia near the Arctic. This was truly terra nullius - land both uninhabited and irrelevant to sovereignty. English and Dutch explorers in the early $17^{\text {th }}$ century repeatedly found evidence of their respective rival's "discovery" but nonetheless asserted rival claims to the islands. Neither group could offer evidence of occupation or effective control of the long uninhabitable place, and their claims grew increasingly tenuous with the activities of Russians, Danes, French, Norwegians, and Germans in subsequent centuries. Denmark, for example, sought to claim Spitsbergen as an extension of Greenland, but went unheeded. By 1900, whaling, trapping, and mining enterprises had become firmly established in the area, and coal mining produced a permanent settlement in 1906 under no legal jurisdiction of any State. Disputes were settled by force. In 1912, plenipotentiaries of Norway, Russia, and Sweden proposed to keep Spitsbergen a terra nullius, and a conference of the European powers and the USA acknowledged this position in 1914, although some participants hoped for a joint sovereignty shared by Norway and Britain if only to keep the peace. World War I interrupted that status quo and, subsequently, the 1920 Treaty of Paris recognized the sovereignty of Norway over the Spitsbergen archipelago (Lansing, 1917; Rudmose Brown, 1919; Nielsen, 1920; KLM, 1938, pp. 79-84; Ulfstein, 1995, pp. 33-71; Fitzmaurice, 2007, p. 3f; Rossi, 2016). So it remains. All territory must now have a sovereign owner.

\section{Boundary Disputes}

However the rationale for occupation of territory may have changed, from discovery in earlier centuries to terra nullius in the $19^{\text {th }}$ century, the possession of territory had always to overcome rival claims. With the new science of topographical surveying, the $19^{\text {th }}$ century witnessed a massive effort to map the globe, in order to define precisely the latitude and longitude of each territorial possession of the civilized nations. When rivals disagreed, their claims were typically submitted to boundary commissions that sought to clarify the dispute and to mark clearly a border.

In this process of clarifying boundaries, we begin to see a shift from royal claims to State claims. In part this was because of the absence of monarchs - republics such as the USA or Liberia (and periodically, France) were without kings and hence were referred to as "States." An ambiguous organization such as the British East India Company may have acted on behalf of the British monarch, but when it set up its own government headquarters in India, Fort St. George, it acted like a State. Likewise, the International African Association acted as and was recognized as a sovereign State. Much of the practice of international law in the $19^{\text {th }}$ century concerned boundaries between rival claimants to territory and the rights of their subjects or citizens to engage in trade and commerce in those territories.

A pair of cases from the $19^{\text {th }}$ century demonstrates two important developments that firmly link territory to statehood in the course of the century. On the one hand, royal claims regarding possession in the name of or on behalf of kings persisted through the century. There is a striking continuity from monarchical to republican practices of claiming territory, as we see with the Northeast Boundary dispute between Britain and the USA. What a king once claimed, a State now claimed. On the other hand, the control of territory became a hybrid form in the course of the century, modeled on the individual's possession of private property. A territorial possession was properly marked by a professional survey in terms of latitude and longitude, and defined by its relations to extant topographical features-in the language of the time, the claim was "particularized." In much the same way that the private individual was free and competent to dispose of all things upon and within his property, the "State" or "Government" that claimed and possessed a territory was said to have jurisdiction over all persons within, or sovereignty over, that place. 


\subsection{The Northeast Boundary Dispute}

Beginning in 1783, the contest between the USA and His Britannic Majesty (HBM) over boundaries continued in two important respects the practices of the earlier "age of exploration." First, the language is still that of "possessions"-the boundary issue is a matter of "tracing and marking" the boundary between the British possessions (or possessions of HBM) in America, and the USA. Second, although the marking of latitude and longitude became standard practice in the $19^{\text {th }}$ century, surveyors persisted with the practice of erecting physical monuments to mark the actual border, much as explorers had done in the earlier age to mark a claim of land. The goal on the part of agents for both governments was to determine the precise limits or boundaries of their respective possessions. What is distinctive to the debate is that, on the one hand, there is a simple continuity on the British side, for possessions of HBM originating in the 1600s remain exactly that in the 1800s, while those that were now claimed by the USA were held jointly by this new and sovereign collective agent, the "United States" and one of its particular constituents, the sovereign State of Massachusetts.

The historical dimension of "possessions" follows clearly the notion that the land "discovered" in the Americas was claimed for a king and is the king's personal possession, to dispose of through "letters patent" to one or another person or company of persons. Key to the Northeastern Boundary dispute was the issuing of letters patent by James I in the early 1600s, which was done prior to the existence of "province, country, district, territory, or place whatsoever in America" (FO 303/2, [p. 15]). Two minor points follow here: one, "territory" is a category of land, unexplored and uninhabited according to European sensibilities; and two, the king in question was a point of contention, since the French king Henry IV had also issued letters patent to French subjects concerning the same lands during the same period. These lands ceased to be French claims after the British defeated the French in 1763 (the "French and Indian" and "Seven Years" War). However, a measure of confusion had persisted, in that some of these lands had arguably been ceded by France to Britain more than a generation earlier, with the Treaties of Utrecht in 1712-13. Ambiguity reigned.

Hence, Ward Chipman for HBM and both James Sullivan and James Austin for the USA emphasize the history of the letters patent issued by James I to Sir William Alexander in 1621 and that issued by Henry IV of France in 1604, in order to respectively identify or disqualify the existence of a place or colony called "Nova Scotia" as an historical point of reference for the contemporary boundary. Central to this dispute was the question of whether or not these two or any other grants of land in the area included the islands in the Bays of Fundy and Passamaquoddy. To Chipman, defending the claims of HBM, Alexander's grant of 1621 had a more "scientific" basis for its incorporation of latitude in its designation; it was accordingly a more reliable claim because, as Chipman repeatedly avers, although "the sundry other preceeding Patents are imaginarily limited by the degrees of the Heavens, ... his is the first national Patent that ever was clearly bounded in America by particular limits upon the Earth" (FO 303/2: [p. 38]).

Chipman accordingly argued that the islands at issue were included within the 1621 claim, which was incorporated into the creation of Nova Scotia in 1765, and they remain British possessions. His rival agents for the USA attacked this assertion from several different points. Sullivan's and Austin's historical argument denied that the islands were ever the possession of anyone in what is now Canada. James I's letters of patent to Alexander in 1621 were not valid, because France had already claimed the territory and granted it in 1540 to Jacques Cartier (FO 303/4: [pp. 8-9]). Even if that were not the case (and admittedly, it was contestable), the islands had already been included in James I's grant of 1620 to Massachusetts Bay Colony; that grant had grandly given "all main land and Islands from 40 degrees latitude north to 48 degrees latitude north and in breadth from Sea to Sea" (FO 303/3: [p. 16]). Even though that colony was dissolved in 1686, the new charter grant of 1691 by William and Mary to Massachusetts Colony granted the same land as the earlier Massachusetts Bay Colony. The subsequent and alleged creation of Nova Scotia did not take any land from Massachusetts (FO 303/3: [pp. 30-31]). By virtue of the US Declaration of Independence, this territory "became part of the new Empire which was thereby created," and in 1783, the British Crown acknowledged this Commonwealth of Massachusetts to be sovereign and independent (FO 303/4: [p. 32]). Sullivan and Austin emphasize the provision in the 1783 Peace Treaty which declared that all islands within 20 leagues from the shores of the USA were to be considered US possessions. As Austin insisted, this was meant to be comprehensive language and no exceptions were made for any islands in the Bays of Fundy and Passamaquoddy (FO 303/3: [pp. 8-9]). ${ }^{4}$

The grant that arguably created Nova Scotia, for example, as "a country and territory" in 1765 consisted of "all lands, grounds, places, soils, woods and wood grounds, havens, ports, rivers, waters and other hereditaments and premises whatsoever" within "the bounds and limits aforementioned" and "all Islands and Islets lying within ten leagues directly

\footnotetext{
${ }^{4}$ Austin undertakes to interpret the treaty by asking 'what is its intention.' He argues that the statement that all islands within 20 leagues of US shores was meant to be comprehensive, contrary to British agent Chipman's argument that HBM did not intend to cede any part of Nova Scotia to the US. See FO 303/4: [p. 3].
} 
opposite to the main land" (FO 303/3: [p. 32]). Although the US agents argued that these latter were already part of Massachusetts, I would emphasize that along with this "country and territory" was granted "a qualified property in and over the soil, and an absolute right of sovereignty to the territory." The private rights of individuals to the soil were retained, but the "right of sovereignty"-also described as "the prerogative of sovereignty" - had been "conveyed to Massachusetts" in 1691. Massachusetts was deemed to be "one legislation and jurisdiction for the more effected protection of the whole against the incursions of our neighboring French and Indians" (FO 303/3: [p. 33]). Although HBM might claim to possess the land, HBM conveyed sovereignty over the land-legislation and jurisdiction-to a State government.

The second major yet thornier issue central to the boundary dispute was the identity of the St. Croix River and its sources - to what degree was it in fact the river "truly intended" by the Treaty of 1783? In defining the boundary between HBM and the USA, the Treaty used the St. Croix River to form part of the boundary, but the Treaty could not be implemented because no one was certain either (a) which river was actually the St. Croix, or, given that other rivers provided multiple sources to what might be called the St. Croix, (b) which of these source rivers was the river boundary "truly intended" by the Treaty. The agents' reports of 1796-97 and 1816-17 offered multiple interpretations. Although the area had been surveyed and mapped multiple times, and although the two governments signed another Convention in 1827 that provided for arbitration of the boundary, the issue remained unresolved until the 1870s. Unlike the question of Islands, this problem of identifying a river was especially a question of scientific expertise in surveying and map-making. What is surprising here is that, although Chipman (the agent for HBM) asserted in 1797 that "Mitchell's map" was erroneous, both governments remained faithful to that map. It had informed the 1783 Treaty, and the Convention of 1827, which provided for arbitration, insisted that Mitchell's map remain one of two valid maps of the region; the other, simply called "Map A," was produced by the 1814 Boundary Commission. ${ }^{5}$ (FO 303/3: [pp. 78-114]; see also FO 303/10; FO 303/11)

In any case, the approach to identifying the boundary presumably defined by the St. Croix River was that routinely used for personal property: one's claim to land was surveyed and its particular location recorded by deed in local registers. Royal or Federal territory accorded with the pattern established by private property, still in use today. But equally important in this case, because private deeds in this territory had long been recognized prior to the Peace Treaty of 1783 , the differentiation of Royal and Federal territory acknowledged private claims to property first and followed that model in differentiating State territory and property. In this instance, private claims to landed property took precedence in defining interstate territorial boundaries.

\subsection{The Liberian Boundary Dispute}

The Liberian case, in comparison, is instructive for its utter failure. Founded in 1822 and declared an independent republic in 1847, Liberia's ongoing boundary conflict with HBM and the British Colony of Sierra Leone began in the wake of a Liberian seizure of a British subject, John Harris, and his ship and his goods in late 1860. According to Liberian authorities, he had been trading in Liberian territory and had failed to furnish either a formal "intention to trade" or the "invoice" of his cargo to the Liberian Collector of Taxes (FO 403/6: [p. 5]). This action begged the question of exactly where were the boundaries between Liberia and the Colony of Sierra Leone.

The Liberian Boundary Dispute persisted intensively for the next two decades and, unresolved, drifted into the $20^{\text {th }}$ century. Britain insisted that areas which Liberia claimed - the Shebar river, Solima, Gallianas, and more - were in fact British territory. Liberia, in response, furnished treaties it had signed with native Chiefs who had ceded all or parts of their respective territories to Liberia and had acknowledged Liberia's "political jurisdiction" over these places. Liberian officials added that Liberia's "sovereignty and political jurisdiction" was a necessary corollary of its earlier treaty with Britain that committed Liberia to Britain's efforts to end the slave trade. Only by dominating the Shebar river and [the] Gallianas [islands] would that be possible (FO 403/6: [pp. 11, 43, 45f]).

British officials both in London and in Sierra Leone were rather disconcerted by Liberia's use of the term "political jurisdiction." Upon realizing that the Republic of Liberia meant effectively "sovereignty," however, they asserted that "political jurisdiction" was not something that local Chiefs had understood and was therefore an invalid stipulation. Moreover, Britain produced several statements on the part of British traders and shippers who did not want their establishments to be in Liberian territory, and found a coalition of local Chiefs who repudiated their treaties with Liberia (FO 403/6: [pp. 4, 80-82]).

\footnotetext{
${ }^{5}$ The North American colonies were surveyed and mapped from the start of settlement, the earliest being a 1585 map of the Cape Hatteras area during the second Roanoke expedition under Walter Raleigh. John Mitchell's "Map of Colonial America" was first produced in 1755 and revised a final time in 1781. It was considered definitive and thus was used for the 1783 treaty. See Thrower, 1996, pp. 116-20.
} 
In the midst of these rival assertions and general confusion about the identity of possessions, as well as repeated Liberian assaults against British subjects in what Liberians considered their territory, Britain proposed two attempts to resolve the boundary dispute, the first in April 1862. Where Liberia preferred to rely on their treaties of cession and to describe their territories in terms of locally accepted "countries" or lands, the British preferred to define "a natural limit [which] ... would be better than an arbitrary limit of a straight line carried into the interior" (FO 403/6: [p. 36]). But because the British had undermined those Liberian treaties and thereby placed doubt on those descriptions of lands, to the detriment of the Liberian cause, and because seasonal rains shifted the course of rivers and their deltas and thereby undercut the British strategy of "natural borders," the first Liberian Boundary Commission made little headway. The second British overture in October 1870, following renewed Liberian actions against British ships and factories, made much more progress (FO 403/6: [p. 129f]). Both parties agreed to have the USA arbitrate in May 1871 and a Mr. Baker was appointed as referee, but then several years were required in order to decide where and when the commissioners would meet, how to appoint someone to survey the rivers and coastal areas, and a host of other questions. In May 1878, a Captain Bradford of the US Navy was finally assigned the task of surveying the area. Meanwhile, the Boundary Commission was dogged by the persistent interference of outstanding claims against Liberia by British traders and shippers, and the Commission abruptly announced its termination in April 1879 (see FO 403/9 and FO 403/11: [p. 153]). After Britain formally annexed the Sewa-Mano region to Sierra Leone in 1883, the Liberian government was induced to sign a boundary treaty in 1885 , but it was poorly worded and caused such local outrage that a third Boundary Commission was established in 1903 - its work was cut off by local insurgencies. France too began to dispute Liberia's borders with French Guinea in 1885, and in 1911 Liberia - whose military forces were no match for its rivals-lost to Britain and France much of the territory that it had claimed at the middle of the $19^{\text {th }}$ century (see Gershoni, 1987).

Unlike its European counterparts, Liberia's treaties with local peoples were discounted, its jurisdiction denied, and its participation in arbitration made irrelevant. One obvious conclusion here, not lost for example on the Japanese or some in the Chinese court, was that military power and the ability to use force were of greatest importance in asserting and maintaining claims. However, for our purposes, the case of Liberia shares an important characteristic with that of the USA. The idea of "sovereignty over territory" was increasingly used interchangeably with "jurisdiction over territory"- a shift in sensibilities as a result of the removal of kings. Non-monarchical States such as the USA or the Republic of Liberia describe their "possession" of territory not only as a claim over land, but also as jurisdiction within or sovereignty over a "particularized" territory.

\section{State Administration of Territory}

This combination of "territorial claims" and "effective occupation" points to the administrative State and its need to secure jurisdiction over a territory in order to provide clear evidence of occupation by means of government administration. Following, for example, the lead of Philip J. Stern (2011), who has argued that the corporate sovereignty of the East India Company (EIC) created imperial State structures prior to the formal creation of a British Empire, the need to formally administer distant territories solidified the bond between territorial administration and State sovereignty. The jurisdiction of new colonial governments over its nationals, its local populations, and itinerant foreigners made a necessity of administering the territory as such. In the $19^{\text {th }}$ century, the tendency was to create one law for all populations within a specific place. Or, as I've phrased it above, the sovereign State became territorial.

I noted above that the British Crown had granted to the Massachusetts Colony in the 1600s the capacity to sustain individual property in the soil and sovereignty over the land. The letters patent of Elizabeth, James I and Charles II which formed and reestablished the Charter of the EIC —in respectively 1601, 1606, 1609, and 1661-did the same, granting the EIC "to have, purchase, receive, possess, enjoy, and retain Lands, Rents, Privileges, Liberties, Jurisdictions, Franchises, and Hereditaments... And also to give, grant, demise, alien, assign, and dispose Lands, Tenements, and Hereditaments..." and "make Peace or War with any Prince or People that are not Christians; and to compense themselves for any Damages." These Charters further specified that the EIC may "hold courts and make laws for or about any of the Matters, Causes, Affairs, or Businesses of the Said Trade, in any Place or Places... within our Dominions, or elsewhere..." (IOR/A/2/3: pp. 6, 28, 41, 55, 76.) Clearly, the EIC was authorized to create a State administration in what became India. As Stern so clearly outlines in The Company-State, the EIC acted in their own name or on behalf of His (or Her) Royal Majesty, but during the revolutions of the 1600s, as Parliament inserted itself into the activities of the EIC in the name of "public interest," the EIC came to act in the name of "the British government." My survey of EIC treaties with local rulers in the late $18^{\text {th }}$ and early $19^{\text {th }}$ centuries shows that the EIC at times acted as "the agent of the British government"; at other times, the "Secretary to the British government" certified EIC treaties (IOR/L/PS/20/G5). And of course, after 1857, the EIC administration of India was reconstituted as a British Colonial administration (justified in Westlake, 1894, pp. 190-231).

Two patterns emerge from the treaties that the EIC signed with local rulers in the $17^{\text {th }}$ and $18^{\text {th }}$ centuries. First, the EIC was clearly motivated to win from local rulers trading rights, including the right to establish factories, minimal (if any) 
duties on their imports, protection of EIC property, and the right to issue a local coinage (IOR/L/PS/20/G5: pp. 9-24). The EIC also purchased or conquered the land upon which its cities and territories would expand: Fort St George (Madras), Bombay (Mumbai), and Fort St. William (Calcutta/Kalikut). A second repeated pattern was the mode of expansion. The EIC agreed to protect some friendly local ruler, engage in armed conflict with another local ruler hostile to the friend, and sign a peace treaty with the hostile ruler. These peace treaties typically result in peace and mutual alliance against each other's enemies, an acknowledgment of the King's possessions, a payment to the EIC for its expenses, the right of the EIC to trade in the King's lands on a duty-free basis, and finally, the withdrawal of English forces (IOR/L/PS/20/G5; see, for example, the treaty between the EIC and Nabob of Oude, August 1765, at p. 52f). Treaties concerning the cession of lands to the EIC very specifically mention that other European nations are to be excluded from these areas and that the "forts, territories, and rights" over such-and-such a place "shall belong in perpetual sovereignty to the Honourable Company" (IOR/L/PS/20/G5: pp. 115f, 271, 398-404). In the $19^{\text {th }}$ century, the administration of such lands is made "in perpetuity to the British Government" IOR/L/PS/20/F7: pp. 234, 251-53). It seems clear from a cursory examination of account records of the EIC that the acquisition of territory had become a routine expenditure, as deficits from the acquisition or conquest of a "province"-which might include costs for "Ships, Troops and Marine Forces"-were to be offset by the revenues anticipated after acquisition (IOR / Mss. Eur. G37/83/5: piece no. 80, dated 26 January 1769). The EIC enterprise, from its start, relied on a striking hybrid of EIC ground forces and the British Navy.

On the occasion of a boundary dispute between the EIC and a neighbor, we find language identical to that in the North American and Liberian disputes - in the absence of European monarchs, it is a matter between States. Consider an example from January 1812: because rivers are constantly changing course and islands and villages are sometimes in EIC territory or that of the Vizier of Oude [Awadh], the EIC proposes that islands belong to "the State on whose frontier the channel may be fordable, and in the case of the channels on both sides of the Island being equal in point of depth, the Island shall be considered to form a part of the territory of that State to which at any point it is the most contiguous" (IOR/L/PS/20/G5: p. 84).

George III's Act to renew the Charter of the EIC in 1813 paid particular attention to civil judicatures and the expansion of courts "for the better Administration of Justice" within EIC territories. In addition to the "provincial courts" established immediately in Company lands, superior courts had been established of necessity in the $17^{\text {th }}$ century: these Company "Admiralty Courts" shared aspects of the Crown's Vice-Admiralty Courts in the Atlantic, but they remained separate institutions - a status reconfirmed by James II in 1686 (Stern, 2011, p.59f). By the $19^{\text {th }}$ century, new problems were posed by the growing diversity of international populations across the subcontinent-including Portuguese, Dutch, French, local natives and those from distant places. What, for example, was Fort St. George to do with natives who might live and work within EIC territory but, given their indigenous status, were also under the jurisdiction of local rulers? The Act of 1813 mandated that natives in the employ of the EIC were subject to the Provincial Courts of the EIC and that justices of the peace within the provinces would have jurisdiction in cases of assault and trespass committed by British subjects upon natives of India (IOR/A/2/17: pp. cix-cxvii).

By mid-century, the prompt administration of newly acquired territories became a priority to British officials, who sought to solve the specific problems of jurisdiction presented by the mixing of nationalities. A case in point was Britain's sudden acquisition in 1848 of the "Orange River Sovereignty" and "British Kaffraria" in southern Africa. Although few officers in the War and Colonial Office were interested in keeping the Orange River Sovereignty (ORS) - and it would soon become the Boer "Orange Free State" in 1854-local officials were immediately perplexed as to how to establish an administration. British Kaffraria was acquired through conquest; it was rightly under military occupation and awaited some formal instrument by the British monarch to make it a colony, whether as a distinct settlement or to be annexed to the Cape Colony. By contrast, the ORS was annexed by proclamation, and the Governor of the Cape Colony and its Council and courts assumed jurisdiction. Some distressed local officials, however, argued that this was not proper procedure (CO 879/1).

First was a question of authority, for the validity of the Governor's action was in doubt. May a British subject such as the Governor declare sovereignty over a foreign land and thereby assert the laws of England and legal character of English subjects in that land? Does the Governor have the power to assert his personal responsibility for the Queen's sovereignty over those territories? And how exactly was the local authority of the Cape Governor to be merged with British sovereignty? The conquest and creation of Natal in 1836, by contrast, had been "legitimated" by William IV's Act of 1836, which created the colony and established law and administration for it. But that Act did not apply to these new circumstances and acquisitions (CO 879/1).

And second was a question of procedure: The annexation of the territory was justified presumably because of the presence of British subjects in the bush. However, local officials argued, colonies were acquired by conquest, cession, or the settlement of unoccupied areas. In the first two cases, conquest and cession, the Crown has power to create an 
administration by means of an Act or Order in Council—as with Natal. Were the ORS an example of the third case, settlement, then the community of British subjects who constitute the ORS might be treated as an extension of the common law of England and, thus, Parliament might intervene in order to establish an administration. But the ORS was not fully a British settlement and the Governor's action was accomplished as a matter of expediency, arguably to prevent anarchy, and awaited some "confirmatory instrument" by either the monarch or Parliament in order to become subject to a legitimate administration (CO 879/1).

The main obstacle to legitimate administration in the ORS lay in the problem of which law applied there, and the numbers of different resident populations provoked the issue. The three main groups-English, Boers, and natives - might reasonably be subject to their own respective laws, as had long been the custom, but the Governor's Proclamation of 1848 left open the question as to which law applied in the ORS: the laws of England, those of Holland, native law, or no law at all. Officials on the ground in 1848 proposed a startlingly new policy: They maintained that one law should govern the territory and all peoples in it. They argued that having a separate law for each "distinct race" would be impracticable, and they did not appreciate the Governor's imposition of the circuit courts of the Cape Colony because, as those courts were constituted, they could not try a foreigner for murder within a British colony, nor could they have jurisdiction over marriage or the inheritance of property involving a foreigner. Local officials in 1848 insisted that whoever was authorized to establish law and its administration for the ORS ought to establish one law for the territory (CO 879/1).

We see here the strong linkage between territory and jurisdiction that was accomplished in the $19^{\text {th }}$ century. In the British case, government at home and in the colonies conscientiously worked to extend British jurisdiction through the extension of law. The sovereign authority of the Crown and Parliament collectively decreed law so as to comprehend all persons within British jurisdiction. Where jurisdiction was found lacking - particularly in cases of natives who lived outside of British colonies but committed crimes within British territory, and foreigners residing inside of British colonies whose behavior was criminal - the Colonial Office, the Foreign Office, the Law Officers of the Crown, the Lord Chancellor, and the Parliamentary Draftsman cooperated to craft law in order to extend British jurisdiction throughout British territories. The centerpieces of this work were the Foreign Jurisdiction Acts and the Orders in Council that they authorized (Johnston, 1973, pp. 70-74).

As we've seen in the cases of the USA and Republic of Liberia, States worked to extend their jurisdiction uniformly across their respective territories. All persons within a State's territory were subject to that State's law. Sir Travers Twiss (1884, p. 260) marked this refocus of sovereignty as territorial jurisdiction, noting that "territorial sovereignty" had come to take precedence over "personal sovereignty" because a State cannot enforce its laws over its subject whilst he is abroad. State sovereignty became territorial sovereignty.

\section{Conclusion: Territorial Sovereignty}

The question raised by many scholars in the past decades is whether developments in the colonial and imperial peripheries of Europe are largely responsible for this shift in territoriality and sovereignty (Branch, 2010; Elden, 2013). This essay confirms such a likelihood, since the language used in the periphery was that of States rather than monarchs. But it is not so simple.

Some novel developments applied both at home and in colonial territory. Advances made in cannon technology, for example, increased their range and correspondingly expanded the distance of domestic territorial waters that States claimed. When such advanced cannon were mounted in either domestic or colonial fortifications, arguments could be made about the expanded "territorial limits" defined by the new technology. For example, British officials in Morocco noted Spain's wish in the 1850s to expand its landholdings surrounding its fortress at Melilla. They were committed to the continuation of the Moroccan emperor, the independence of Tangier, and British control of Gibraltar but, they acknowledged, "the range of guns around a fortress has ... become a very elastic limit of territorial jurisdiction." British officials very much wanted to maintain Britain's own right to expand its territorial jurisdiction by virtue of better cannon. Hence they did not oppose Spain's effort in March 1859 to enlarge its "concession" at Melilla, but they feared that this was a surreptitious move by Spain to increase its forces in North Africa in order to expand its territorial limits by force (FO 413/1).

Territoriality in the $19^{\text {th }}$ century posed the question of exclusive State jurisdiction. In the Anglo-American world, legal positivists emphasized the sovereignty of the State in asserting the State's authority to create and to sanction law, and they correspondingly elevated the State in international law. Each State strove to assert its complete jurisdiction over the criminal and civil matters of persons within its territory; and this work was an effort to consolidate State authority over all aliens within its territory and over all its subjects at home and abroad and on its ships at sea. State control of territory came to mark a State's sovereignty—its absolute jurisdiction within its own territory. 


\section{References}

Agnew, J. (1994). The Territorial Trap: The Geographical Assumptions of International Relations Theory. Review of International Political Economy, 1(1), 53-80. https://doi.org/10.1080/09692299408434268

Alliès, P. (1980). L'invention du territoire. Grenoble: Presses universitaires de Grenoble.

Anghie, A. (2004). Imperialism, Sovereignty, and the Making of International Law (Cambridge: Cambridge University Press. https://doi.org/10.1017/CBO9780511614262

"Arbitral Award of the President of the United States, Regarding the Dispute between Portugal and the United Kingdom about the Sovereignty over the Island of Bulama ... Decision of 21 April 1870.” In United Nations, Reports of International Arbitral Awards, 28(2007), 131-39.

Branch, J. (2010). 'Colonial Reflection' and Territoriality: The Peripheral Origins of Sovereign Statehood. European Journal of International Relations, 18(2), 277-297. https://doi.org/10.1177/1354066110383997

Branch, J. (2011). Mapping the Sovereign State: Technology, Authority and Systemic Change. International Organization, 65(1), 1-36. https://doi.org/10.1017/S0020818310000299

CO (Colonial Office): UK, The National Archives, Colonial Office Files.

Collins, S. L. (1989). From Divine Cosmos to Sovereign State. Oxford: Oxford University Press.

Crampton, J. W., \& S. Elden. (2006). Space, Politics, Calculation: An Introduction. Social and Cultural Geography, 7(5), 681-85. https://doi.org/10.1080/14649360600971168

Delaney, D. (2005). Territory: A Short Introduction. Oxford: Blackwell. https://doi.org/10.1002/9780470773925

Díaz, B. (1963). The Conquest of New Spain, trans. J.M. Cohen. Harmondsworth: Penguin.

Elden, S. (2013). A History of Territory. Chicago: University of Chicago Press.

Engelhardt, É. (1886). Étude sur la déclaration de la conférence de Berlin relative aux occupations. Revue de droit international et de législation comparée, 18, 433-41, 573-86.

Fitzmaurice, A. (2007). The Genealogy of Terra Nullius. Australian Historical Studies, 129, 1-15. https://doi.org/10.1080/10314610708601228

Fitzmaurice, A. (2012). Discovery, Conquest, and Occupation of Territory. In The Oxford Handbook of the History of International Law, ed. B. Fassbender and A. Peters, pp. 840-61. Oxford: Oxford University Press. https://doi.org/10.1093/law/9780199599752.003.0036

FO (Foreign Office): UK, The National Archives, Foreign Office Files.

Forsberg, T. (2003). The Ground Without Foundation? Territory as a Social Construct." Geopolitics, 8(2), 7-24. https://doi.org/10.1080/714001038

Fry, J. D., \& M. H. Loja. (2014). The Roots of Historic Title: Non-Western Pre-Colonial Normative Systems and Legal Resolution of Territorial Disputes. Leiden Journal of International Law, 27, 727-54. https://doi.org/10.1017/S0922156514000284

"General Act of the Conference ... respecting the Congo, signed at Berlin 26 February 1885." In The Consolidated Treaties Series, ed. Clive Parry (Dobbs Ferry, NY: Oceana, 1969-81), vol. 165, 485-502.

Gershoni, Y. (1987). The Drawing of Liberian Boundaries in the Nineteenth Century: Treaties with African Chiefs versus Effective Occupation." International Journal of African Historical Studies, 20(2), 293-307. https://doi.org/10.2307/219844

Gioia, A. (2013). Historic Titles. Max Planck Encyclopedia of Public International Law. [Online edition]. London: Oxford University Press.

Gottmann, J. (1973). The Significance of Territory. Charlottesville, University Press of Virginia.

Hannah, M. G. (2000). Governmentality and the Mastery of Territory in $19^{\text {th }}$-Century America. Cambridge: Cambridge University Press.

Harris, S. M. (2015). Between Law and Diplomacy: International Dispute Resolution in the Long Nineteenth Century. Ph.D. Dissertation, University of California, Davis.

Hill, N. (1945). Claims to Territory in International Law and Relations. London: Oxford University Press.

Howland, D. (2016). International Law and Japanese Sovereignty: The Emerging Global Order in the $19^{\text {th }}$ Century. New York: Palgrave Macmillan. https://doi.org/10.1007/978-1-137-56777-2 
Huh, S. (2015). Title to Territory in the Post-Colonial Era: Original Title and Terra Nullius in the ICJ Judgments on Cases Concerning Ligitan/Sipadan (2002) and Pedra Branca (2008). European Journal of International Law, 26(3), 709-25. https://doi.org/10.1093/ejil/chv036

IOR (India Office Records): British Library (London), India Office Records Files.

Johnston, W. R. (1973). Sovereignty and Protection: A Study of British Jurisdictional Imperialism in the Late Nineteenth Century. Durham: Duke University Press.

KLM: Keller, A. S., O. J. Lissitzyn, \& F. J. Mann. (1938). Creation of Rights of Sovereignty through Symbolic Acts, 1400-1800. N.Y.: Columbia University Press. https://doi.org/10.2307/1333430

Koskenniemi, M. (2001). The Gentle Civilizer of Nations: The Rise and Fall of International Law 1870-1960. Cambridge: Cambridge University Press. https://doi.org/10.1017/CBO9780511494222

Kraotochwil, F. (1986). Of Systems, Boundaries, and Territoriality: An Inquiry into the Formation of the State System. World Politics, 39(1), 27-52. https://doi.org/10.2307/2010297

Kuntz, F. (2015). Aporias: The International Relation, Interrelated Sovereigns, the Human Individual, and Power-Knowledge. Ph.D. Dissertation, University of Bielefeld.

Lansing, R. (1917). A Unique International Problem. American Journal of International Law, 11(4), 763-771. https://doi.org/10.2307/2188203

Locke, J. (1988). Two Treatises of Government, ed. Peter Laslett. Cambridge, Cambridge University Press. https://doi.org/10.1017/CBO9780511810268

Lowe, V. (2007). International Law. Oxford: Oxford University Press. https://doi.org/10.1093/he/9780199268849.001.0001

Martitz, F. de. (1887). Occupation des territoires. Revue de droit international et de legislation comparée, 19, 371-76.

Miéville, C. (2006). Between Equal Rights: A Marxist Theory of International Law. Chicago: Haymarket.

Mostart, H. (2013). Aboriginal Title. In Max Planck Encyclopedia of Public International Law. [Online edition]. London: Oxford University Press.

Murphy, A. B. (1996). The Sovereign State System as Politico-Territorial Ideal. In The Sovereign State as Social Construct, ed. T. Biersteker and C. Weber, pp. 81-120. Cambridge: Cambridge University Press. https://doi.org/10.1017/CBO9780511598685.004

Nielsen, F. K. (1920). The Solution of the Spitsbergen Question. American Journal of International Law, 14(1/2), 232-235. https://doi.org/10.2307/2187849

"Quatrième commission d'études: Examen de la théorie de la conférence de Berlin de 1885, sur l'occupation des territoires." Annuaire de l'Institut de droit international 9 (1888), 243-55.

Resolutions of the Institute of International Law Dealing with the Law of Nations, ed. James Brown Scott (N.Y.: Oxford University Press, 1916).

Rossi, C. R. (2016). 'A Unique International Problem': The Svalbard Treaty, Equal Enjoyment, and Terra Nullius: Lessons of Territorial Temptation from History. Washington University Global Studies Law Review 15, 93-136.

Rudmose, B. R. N. (1919). Spitsbergen, Terra Nullius. Geographical Review, 7(5), 311-321. https://doi.org/10.2307/207588

Ruggie, J. G. (1993). Territoriality and Beyond: Problematizing Modernity in International Relations. International Organization, 47(1), 139-74. https://doi.org/10.1017/S0020818300004732

Sahlins, P. (1989). Boundaries: The Making of France and Spain in the Pyrenees. Berkeley: University of California Press.

Simsarian, J. (1938). The Acquisition of Legal Title to Terra Nullius. Political Science Quarterly, 53(1), 124-128. https://doi.org/10.2307/2143606

Song, N. (2017). The Journey towards 'No Man's Land': Interpreting the China-Korea Borderland within Imperial and Colonial Contexts. The Journal of Asian Studies, 76(4), 1035-1058. https://doi.org/10.1017/S002191181700078X

Steinberg, P. E. (2001). The Social Construction of the Ocean. New York: Oxford University Press.

Stern, P. J. (2011). The Company-State: Corporate Sovereignty and the Early Modern Foundations of the British Empire in India. Oxford: Oxford University Press. https://doi.org/10.1093/acprof:oso/9780195393736.001.0001 
Strandsbjerg, J. (2010). Territory, Globalization, and International Relations: The Cartographic Reality of Space. New York: Palgrave Macmillan. https://doi.org/10.1057/9780230304130

Strauss, M. J. (2015). Territorial Leasing in Diplomacy and International Law. Leiden: Brill Nijhoff. https://doi.org/10.1163/9789004293625

Thrower, N. J. W. (1996). Maps and Civilization: Cartography in Culture and Society. Chicago: University of Chicago Press.

Turnbull, D. (1993). Maps as Territories: Science is an Atlas. Chicago: University of Chicago Press.

Twiss, T. (1884). The Law of Nations Considered as Independent Political Communities: On the Rights and Duties of Nations in Time of Peace, $2^{\text {nd }}$ ed. Oxford: Clarendon Press.

Ulfstein, G. (1995). The Svalbard Treaty: From Terra Nullius to Norwegian Sovereignty. Oslo: Scandinavian University Press.

Van der Linden, M. (2014). The Acquisition of Africa (1870-1914): The Nature of Nineteenth-Century International Law. Oisterwijk: Wolf Legal Publishers.

Waldron, J. (1988). The Right to Private Property. Oxford: Clarendon.

Westlake, J. (1894). Chapters on the Principles of International Law. Cambridge: University Press.

\section{Copyrights}

Copyright for this article is retained by the author(s), with first publication rights granted to the journal.

This is an open-access article distributed under the terms and conditions of the Creative Commons Attribution license which permits unrestricted use, distribution, and reproduction in any medium, provided the original work is properly cited. 